\title{
Retrospective study on the effect of Body Mass Index (BMI) on maternal and neonatal outcome
}

\author{
Pooja M. Shah, Anagha K. Chatrapati, Pooja K. Bandekar*
}

Department of Obstetrics and Gynecology, Nowrosjee Wadia Maternity Hospital, Acharya Donde Marg, Parel, Mumbai, Maharashtra, India

Received: 06 January 2018

Accepted: 31 January 2018

*Correspondence:

Dr. Pooja K. Bandekar,

E-mail: pujuobgy@gmail.com

Copyright: () the author(s), publisher and licensee Medip Academy. This is an open-access article distributed under the terms of the Creative Commons Attribution Non-Commercial License, which permits unrestricted non-commercial use, distribution, and reproduction in any medium, provided the original work is properly cited.

\section{ABSTRACT}

Background: Obesity has become health problem worldwide. Prevalence of obesity has increased globally with more incidence observed in female than male. Objective of present study was assessment of maternal outcome in term of associated medical disorder and mode of delivery and assessment of neonatal outcome.

Methods: The retrospective study performed at Nowrosjee Wadia Maternity Hospital, a tertiary care centre between $1^{\text {st }}$ January 2017 to $30^{\text {th }}$ November 2017. Total 64 patients were enrolled. Maternal and neonatal outcomes were studied in all nulligravida women with high BMI using logistic regression adjusted for confounding variable.

Results: Women with high BMI were at increased risk of hypertensive disorder of pregnancy $(40.65 \%)$, diabetes $(7.81 \%)$, induction of labour $(62.5 \%)$, instrumental delivery $(14.06 \%)$, operative intervention $(42.18 \%)$, prolonged hospital stay and NICU admission (26.56\%).

Conclusions: This study observes increase risk of adverse outcome in pregnant women with high BMI.

Keywords: Body mass index, Deep transverse arrest, Gestational diabetes mellitus, Induction of labour, Neonatal intensive care unit, Non progress of labour

\section{INTRODUCTION}

Obesity has become health problem worldwide. Prevalence of obesity has increased globally with more incidence observed in female than male. Due to improvement in the economic status along with the faulty dietary habits and increase in the caloric intake prevalence of obesity has increased in general population of India. ${ }^{1}$ Over-weight and obesity in Indian women has increased from 10.6 to $14.8 .^{2}$

According to WHO criteria BMI is classified into 6 categories. $^{3}$

According to several studies it was observed that obesity puts the antenatal patient at the increased risk of developing chronic hyper tension, pre-eclampsia, pregestational diabetes mellitus, gestational diabetes mellitus, pre term labor, dysfunctional labor, instrumental deliveries, caesarean section, pro-long hospital stay, poor bone healing. And neonates of the obese women were at the increased risk of congenital anomalies, preterm deliveries, large for gestational age and increased NICU admission.

\section{METHODS}

Study was conducted retrospectively at Nowrosjee Wadia Maternity Hospital between the period of $1^{\text {st }}$ January 2017 to $30^{\text {th }}$ November 2017 . It is a routine practice at the institute to categories patient with $\mathrm{BMI} \geq 25$ as a high risk 
pregnancy card and such patients were selected for data assimilation from the medical record department.

Subjects were classified as per WHO criteria into 3 categories.

Table 1: BMI for Obese class.

\begin{tabular}{|ll|}
\hline Class & BMI \\
\hline Obese Class I & $30-34.99 \mathrm{~kg} / \mathrm{m}^{2}$ \\
\hline Obese Class II & $35-39.99 \mathrm{~kg} / \mathrm{m}^{2}$ \\
\hline Obese Class III & $40 \mathrm{~kg} / \mathrm{m}^{2}$ and above \\
\hline
\end{tabular}

Maternal and perinatal outcome were studied in above subjects.

\section{Inclusion criteria}

- $\quad$ Primigravida

- $\quad \mathrm{BMI} \geq 30$

- $\quad$ Singleton pregnancy.

\section{Exclusion criteria}

- Multigravida

- $\quad \mathrm{BMI}<30$

- Multiple pregnancy

- Previous myomectomy.

Based on medical records, the patients were categorised according to the presence of pre-existing medical illnesses, development of hypertension, glucose intolerance, development of antenatal fetal complications, various modes of delivery and fetal outcome based on APGAR score and need for NICU admission.

\section{Statistical analysis}

Logistic regression adjusted for confounding variable.

\section{RESULTS}

64 women were recruited in the study considering the inclusion criteria of $\mathrm{BMI} \geq 30$. As per their BMI, they were categorized as below.

Table 2: Categorization of patient.

\begin{tabular}{|l|l|}
\hline Class & Number of patients \\
\hline Class I & 38 \\
\hline Class II & 20 \\
\hline Class III & 6 \\
\hline
\end{tabular}

In present study it was found 7 out of $64(11 \%)$ women had chronic hyper-tension, 19 (29.6\%) had preeclampsia, $1(1.5 \%)$ patient had pre-existing heart disease, $1(1.5 \%)$ had pre-gestational diabetes and 4 $(6.25 \%)$ had gestational diabetes mellitus. 2 (3.1\%) patient came with pre-term labour, $3(4.68 \%)$ patients had
IUGR and for $12(18.7 \%)$ patients were extended till 40 weeks (Table 3).

Table 3: Antenatal complication.

\begin{tabular}{|c|c|c|c|c|}
\hline Complications & $\begin{array}{l}\text { Class I } \\
(38)\end{array}$ & $\begin{array}{l}\text { Class } \\
\text { II (20) }\end{array}$ & $\begin{array}{l}\text { Class } \\
\text { III (6) }\end{array}$ & $\begin{array}{l}\text { Total } \\
(64)\end{array}$ \\
\hline $\begin{array}{l}\text { Chronic } \\
\text { hypertension }\end{array}$ & - & $\begin{array}{l}5 \\
(25 \%)\end{array}$ & $\begin{array}{l}2 \\
(33 \%)\end{array}$ & $\begin{array}{l}7 \\
(11 \%)\end{array}$ \\
\hline Preeclampsia & $\begin{array}{l}8 \\
(21 \%)\end{array}$ & $\begin{array}{l}10 \\
(50 \%)\end{array}$ & $\begin{array}{l}1 \\
(16.6)\end{array}$ & $\begin{array}{l}19 \\
(29.6 \%)\end{array}$ \\
\hline $\begin{array}{l}\text { Pre-existing } \\
\text { heart disease }\end{array}$ & $\begin{array}{l}1 \\
(2.63 \%)\end{array}$ & - & - & $\begin{array}{c}1 \\
(1.5 \%)\end{array}$ \\
\hline $\begin{array}{l}\text { Pre-gestational } \\
\text { diabetes }\end{array}$ & - & - & $\begin{array}{l}1 \\
(16.6 \%)\end{array}$ & $\begin{array}{l}1 \\
(1.5 \%)\end{array}$ \\
\hline GDM & $\begin{array}{l}2 \\
(5.2 \%)\end{array}$ & - & $\begin{array}{l}2 \\
(33 \%)\end{array}$ & $\begin{array}{l}4 \\
(6.25 \%)\end{array}$ \\
\hline IUGR & - & $\begin{array}{l}3 \\
(15 \%)\end{array}$ & - & $\begin{array}{l}3 \\
(4.68 \%)\end{array}$ \\
\hline Pre-term & - & $\begin{array}{l}2 \\
(10 \%)\end{array}$ & - & $\begin{array}{l}2 \\
(3.1 \%)\end{array}$ \\
\hline Post-term & $\begin{array}{l}8 \\
(21 \%)\end{array}$ & $\begin{array}{l}4 \\
(20 \%)\end{array}$ & - & $\begin{array}{l}12 \\
(18.7 \%)\end{array}$ \\
\hline
\end{tabular}

Out of 64 patients, $21(32.81 \%)$ went in spontaneous labour, $40(62.5 \%)$ required induction of labour, the common indications for induction of labour being post datism, gestational and pre-existing diabetes, preeclampsia. 3 (11.11\%) were elective LSCS done for breech presentation and Cephalopelvic disproportion. Among 37 patients who delivered vaginally, 28 (43.75\%) had normal vaginal delivery and $9(14.06 \%)$ required instrumental delivery (Table 4).

Table 4: Mode of delivery.

\begin{tabular}{|c|c|c|c|c|}
\hline & $\begin{array}{l}\text { Class I } \\
\text { (38) }\end{array}$ & $\begin{array}{l}\text { Class } \\
\text { II (20) }\end{array}$ & $\begin{array}{l}\text { Class } \\
\text { III (6) }\end{array}$ & Total (64) \\
\hline Induced & $\begin{array}{l}19 \\
(50 \%)\end{array}$ & $\begin{array}{l}15 \\
(80 \%)\end{array}$ & $\begin{array}{l}6 \\
(100 \%)\end{array}$ & $\begin{array}{l}40 \\
(62.5 \%)\end{array}$ \\
\hline $\begin{array}{l}\text { Spontaneous } \\
\text { labor }\end{array}$ & $\begin{array}{l}17 \\
(44.7 \%)\end{array}$ & $\begin{array}{l}4 \\
(20 \%)\end{array}$ & - & $\begin{array}{l}21 \\
(32.81 \%)\end{array}$ \\
\hline $\begin{array}{l}\text { Instrumental } \\
\text { delivery }\end{array}$ & $\begin{array}{l}4 \\
(10.5 \%)\end{array}$ & $\begin{array}{l}4 \\
(20 \%)\end{array}$ & 1 & $9(14.06 \%)$ \\
\hline LSCS & $\begin{array}{l}16 \\
(42 \%)\end{array}$ & $\begin{array}{l}6 \\
(30 \%)\end{array}$ & $\begin{array}{l}5 \\
(100 \%)\end{array}$ & $\begin{array}{l}27 \\
(42.18 \%)\end{array}$ \\
\hline $\begin{array}{l}\text { Normal } \\
\text { vaginal birth }\end{array}$ & $\begin{array}{l}18 \\
(47.36 \%)\end{array}$ & $\begin{array}{l}10 \\
(50 \%)\end{array}$ & - & $\begin{array}{l}28 \\
(43.75 \%)\end{array}$ \\
\hline
\end{tabular}

Indication of instrumental delivery was foetal distress (forceps), decrease maternal effort (vacuum) and occipital posterior (forceps) (Table 5).

Table 5: Induction of assisted vaginal delivery.

\begin{tabular}{|llll|}
\hline $\begin{array}{l}\text { Decrease } \\
\text { maternal effort }\end{array}$ & $2(5.26 \%)$ & - & $1(16.86)$ \\
\hline Fetal bradycardia & $2(5.26 \%)$ & $3(15 \%)$ & - \\
\hline OP & - & $1(5 \%)$ & - \\
\hline
\end{tabular}


27 patients had LSCS out of which 3 (11.11\%) were elective and remaining $24(88.89 \%)$ were required emergency LSCS. The commonest indication of LSCS was foetal distress followed by failure of induction and NPOL (Table 6).

Table 6: Indication of LSCS.

\begin{tabular}{|lllll|}
\hline CPD & Class I & Class II Class III & Total \\
\hline NPOL & $2(5.26 \%)$ & & & $2(3.13 \%)$ \\
\hline $\begin{array}{l}\text { Mal- } \\
\text { presentation }\end{array}$ & $2(5.26 \%)$ & $3(50 \%)$ & $5(7.81 \%)$ \\
Failure of & 6 & & & 2 \\
induction & $(15.78 \%)$ & & $(33.33 \%)$ & $(12.5 \%)$ \\
\hline Fetal & 4 & 4 & 1 & 10 \\
distress & $(10.52 \%)$ & $(20 \%)$ & $(16.6 \%)$ & $(15.6 \%)$ \\
\hline DTA & - & $1(5 \%)$ & & $1(1.56 \%)$ \\
\hline
\end{tabular}

NICU admissions were found more in patient with high BMI (Table 7). The most common cause of NICU admission was glucose monitoring in neonate, MSAF, IUGR, hyper-bilirubinaemia (Table 8).

Table 7: Neonatal outcome.

\begin{tabular}{|lllll|}
\hline NICU & Class I & Class II & Class III & Total \\
required & $(18.42 \%)$ & $6(30 \%)$ & 4 & 17 \\
\hline $\begin{array}{l}\text { NICU not } \\
\text { required }\end{array}$ & 31 & 14 & $(66.67 \%)$ & $(26.52 \%)$ \\
\hline
\end{tabular}

Table 8: Indication of NICU admission.

\begin{tabular}{|llll|}
\hline & Class I & Class II & Class III \\
\hline IUGR/LBW & - & $2(10 \%)$ & \\
\hline Macrosomia & - & - & $1(16.6 \%)$ \\
\hline Neonatal asphyxia & - & $2(10 \%)$ & \\
\hline MSAF & $4(10.52 \%)$ & - & 1 \\
\hline Hypo-glycaemia & $3(7.89 \%)$ & $1(5 \%)$ & $4(66.67 \%)$ \\
\hline Hyper-bilirubinaemia & - & 1 & \\
\hline
\end{tabular}

In present study, there were certain incidental finding such as

- Obese women underwent reproductive enhancing procedure,

- Women with high BMI had longer hospital stay as compared to other

- The incident of wound gape was more in obese women.

\section{DISCUSSION}

Obesity is considered as a high risk factor as it has adverse impact on the maternal and foetal outcome. Obesity is classified by various method, but Body Mass Index is most commonly used. ${ }^{4}$

BMI is calculated as follow:
BMI $=$ Weight $(\mathrm{Kg}) /$ Height $^{2}(\mathrm{~m})$

In the study perform by Ovesen $\mathrm{P}$ et al the incidence of glucose intolerance during pregnancy is $3 \%$ to $8 \%$, higher in obese as compared to normal weight women. ${ }^{5}$ Similar finding was found in our study with $7.81 \%$ obese patient suffered from glucose intolerance.

In similar study perform by Bhattacharya $S$ et al it was found that incidence of pre-eclampsia, gestational hyper tension, IOL, emergency LSCS was higher in the moderately obese women. ${ }^{6}$ Same observation was found in our studies with higher incidence of above finding in obese patient.

As per study done by Dasgupta A et al, it was found that the incidence of hypertensive disorder in pregnancy [chronic hypertension (28\%) and preeclampsia (18\%)] was significantly high in obese patient and the rate of LSCS $46 \%$ and instrumental delivery was found high in the obese patient post LSCS wound were high in obese patient. ${ }^{7}$ Similar result was found in our study with chronic hypertension (11\%), preeclampsia (29.6\%) and the rate of LSCS was more in obese patient $(42.18 \%)$.

According to Callaways L K It el, new born of morbidly obese women require NICU admission more often. ${ }^{8}$ In our study $8(50 \%)$ out of 17 went to NICU for postdelivery sugar monitoring in view of maternal deranged sugar level. 2 went for low birth weight.

In study performed by Athukorala $\mathrm{C}$ et al, women who are obese have an increases risk complication during pregnancy in term of gestational diabetes, pre-eclampsia, increase rate of LSCS. ${ }^{9}$ Similar finding is found in present study.

According to Crane JM et al, in women who were obese with excess weight gain during pregnancy had more incidence of macrosomic babies (weight $>4 \mathrm{~kg}$ ), neonatal metabolic abnormlity. ${ }^{10}$

Rehman MM et al performed a systematic review and metaanalysis of 42 studies on maternal BMI and adverse outcomes in low and middle income countries in 2015. Compared with mothers with normal BMI, overweight or obese mothers were at increase odds of gestational diabetes, pregnancy induce hypertension, preeclampsia, caesarean delivery and postpartum haemorrhage. Treatment and prevention of maternal underweight, overweight or obesity may help reduce the burden on maternal and child health in developing countries. ${ }^{11}$

Pillai R et al, compared women of normal weight with obese women and found to have more risk of hypertensive disorder of pregnancy, gestational diabetes mellitus, induction of labor, caesarean section postpartum haemorrhage and macrosomia. In class III obesity there was additional risk of preterm delivery, still birth, prolong stay and increased NICU admission. ${ }^{12}$ 


\section{CONCLUSION}

Obesity should be considered as a high risk factored during pregnancy and women should be counsel regarding maternal and foetal complication associated with obesity to obtain optimal results. Health care professional should proactively screen obese women for gestational diabetes, hypertensive disorder of pregnancy and delivery should be conducted in well-equipped tertiary care centre.

Funding: No funding sources Conflict of interest: None declared

Ethical approval: Not required

\section{REFERENCES}

1. Gulati S, Mishra A. Abdominal Obesity and type 2 diabetes in Asian Indians; dietary strategies including edible oils, cooking practices and sugar intake. Eur J Clin Nutr. 2017;71(7):850-7.

2. Balarajan Y, Villamar E. Nationally represent at survey show recent increase in prevalence of overweight and obesity among women of reproductive age in Bangladesh, Nepal and India. J Nutr. 2009;139:2139-44.

3. WHO Global Database on Body Mass Index Available at http://apps.who.int/bmi/index.jsp

4. Cunningham FG, Lenovo KJ, Bloom SL, Houth JC, Gilstrap L, Wenstram KD. obesity Williams obstetrics 24th edition, New York: MC Graw-Hill companies;2005:946.

5. Ovesen P, Rasmussen S, Kesmodel U. Effect of prepregnancy maternal overweight and obesity on pregnancy outcome. Obstet Gynecol. 2011;118(2):305-12.
6. Bhattacharya S, Campbell DM, Listion WA, Bhattacharya S. Effect of body mass index on pregnancy outcome in nulliparous women delivering singleton babies. BMC Public Health. 2007;7:168.

7. Dasgupta A, Harichandrakumar KT, Syed Habeebullah S. Pregnancy outcome among obese Indians - a prospective cohort study in a tertiary care centre in south India. Int J Sci Stud. 2014;2(2):13-8.

8. Callaways LK, Prins JB, Chang AM, Mclntyre HD. The prevalence and impact of overweight and obesity in an Australian obstetric population. Med J Aust. 2006 Jan;184(2):56-9.

9. Athukorala C, Rumbold AR, Willsin KJ,Crowther CA. The risk of adverse pregnancy outcomes in women who are overweight or obese. BMC Pregnancy Childbirth. 2010;10:56.

10. Crane JM, White J, Murphy P, Burrage L, Hutchens D. The effect of gestational weight gain by body mass index on maternal and neonatal outcomes. J Obstet Gynaecol Can. 2009 Jan;31(1):28-35.

11. Rahman MM, Abe SK, Kanda M, Narita S, Rahman MS, Bilano V et al. Maternal body mass index and risk of birth and maternal health outcomes in lowand middle-income countries: a systematic review and meta-analysis. Obstet Rev. 2015;16(9):758-70.

12. Scott-Pillai R, Spence D, Cardwell CR, Hunter A, Holmes VA. The impact of body mass index on maternal and neonatal outcomes: a retrospective study in a UK obstetric population, 2004-2011. 2013;120(8):932-9.

Cite this article as: Shah PM, Chatrapati AK, Bandekar PK. Retrospective study on the effect of Body Mass Index (BMI) on maternal and neonatal outcome. Int J Reprod Contracept Obstet Gynecol 2018;7:1070-3. 